\title{
Moose and snowshoe hare competition and a mechanistic explanation from foraging theory
}

\author{
G.E. Belovsky \\ School of Natural Resources, The University of Michigan, Ann Arbor, MI 48109, USA
}

\begin{abstract}
Summary. Moose (Alces alces) and snowshoe hare (Lepus americanus) appear to compete with each other. This was determined using the "natural experiments" of populations found in sympatry and allopatry on islands at Isle Royale National Park, Michigan, and manipulated exclosures. The population densities from these areas are fit to a series of competition models based upon different competitive mechanisms (Schoener 1974a), using non-linear regression techniques. A model of competition for food where the food can be separated into exclusively used and shared categories is found to predict observed densities of moose and hare best. Finally, the competition model's parameters (fraction of food shared and competition coefficients) are shown to agree with values predicted independently from a foraging model.
\end{abstract}

\section{Introduction}

Competition between animal populations has received much attention from ecologists. Since Gause's (1934) pioneering laboratory experiments showing that the Lotka-Volterra competition equations could be applied to a real system (Lotka 1932; Volterra 1926), many researchers have attempted to study and model competitive interactions (Schoener 1983). Some studies find that the Lotka-Volterra model works well (Gause 1934; Crombie 1947; Neyman et al. 1956; Vandermeer 1969; Werner 1977), while others find that it does not fit the observed data and a non-linear model is more appropriate (Ayala 1971; Wilbur 1972; Gilpin and Justice 1972; Gilpin and Ayala 1973, 1976; Ayala et al. 1973; Neill 1974; Schoener 1974a, 1975; Smith-Gill and Gill 1978; Abrams 1980a, b, $1981 \mathrm{a}, \mathrm{b}$; Tilman 1980, 1982; Tilman et al. 1982). In response to the difficulties encountered with the Lotka-Volterra model and its limited mechanistical justification, Schoener (1973, 1974 a, 1976, 1978) has developed a series of models based upon:

1) exploitation of completely overlapping resources with a fixed energy input,

2) interference with time limitation,

3) interference with fixed energy inputs, and

4) exploitation of partially overlapping resources with a fixed energy input.

Only models 1 and 2 result in the Lotka-Volterra model.

Schoener $(1974 \mathrm{a}, 1975)$ has applied the above four models to field data on island lizard populations, demonstrating that isoclines can be computed given data on sympatric and allopatric populations. Although other researchers have applied mechanistic models to their data (Gilpin and Ayala 1976; Abrams $1981 \mathrm{a}, \mathrm{b}$; Tilman 1982) or suggested the use of such models (Seegmiller and Ohmart 1981), Schoener's studies (1974a, 1975) are the only examples which apply a set of alternative mechanistic models to try to discern the precise mechanisms of competition. Finally, with mechanistic models it is desirable to predict the competition parameters given behavioral, physiological or anatomical characteristics of the species involved, thereby enabling a priori predictions concerning competitive interactions (Brown 1981).

This paper attempts to examine these issues for two herbivores, moose (Alces alces) and snowshoe hare (Lepus americanus) at Isle Royale National Park, Michigan. Nonlinear regression analysis (Marquardt 1963; Conway et al. 1970; Schoener 1974a), as applied to field population data, indicates that exploitative competition for food occurs where some food items are exclusively used and others are shared. The shared and exclusive food items are demonstrated to arise from the very similar, but different demands for food item sizes and quality arising from the foraging strategies of these two herbivores (Belovsky 1978, 1981, in press). Furthermore, these competitive dynamics vary with forest type and food availability.

\section{Study area}

Isle Royale is a $510-\mathrm{km}^{2}$ archipelago in Lake Superior. Moose and snowshoe hare are the only two terrestrial mammalian herbivores present throughout the year; beaver (Castor canadensis) and muskrat (Ondatra zibethicus) are largely aquatic, and insects are foraging only in summer. One set of data was obtained from a series of islands, Washington, Booth, and Grace Islands, and from the point on Isle Royale off which they lie. These areas have similar canopies composed of Abies balsamea, Picea mariana, and Betula papyrifera. The boreal forest is maintained by the cool-moist effect of Lake Superior. The islands are free of the hare's terrestrial predator, the red fox (Vulpes vulpes), and the predator is very scarce in the main island site; in three years only one scat was found. The islands differ from the main island in moose utilization of forage. The differing moose forage use arises because the islands are too small to have year-round indigenous moose populations and moose must swim to reach them, so that forage use by moose depends upon transient individuals. Therefore, the islands provide a natural experimental situation with 
moose forage use limited by their colonization rate and hare forage use set by residents, whose numbers are assumed to be in equilibrium with the limited density of moose.

A second set of data was collected from twelve areas on the main island. These areas differed in forest composition. Some were very similar to the above boreal study areas, while others were primarily northern hardwood. The classification of forest types in this study follows that proposed by Krefting et al. (1970). All these mainland areas have terrestrial predators (Vulpes fulva, Canis lupus and possibly, Lynx canadensis).

\section{Methods}

The methods for measuring and modelling population densities for moose and hare are presented below.

\section{Field data}

At each study site a series of $2-\mathrm{m}$ radius plots were established along a transect at $100-\mathrm{m}$ intervals. All study areas were not equally sampled, either because several forest types were encountered or due to time considerations, as some areas were relatively inaccessible. The number of plants with twigs within $2.8-\mathrm{m}$ of the ground, the height to which moose can feed, were counted in each plot. Also, the number of twig stubs was counted. Removals by moose and hare could be separated since items fed upon by moose have a rough-torn appearance, while hare leave a clean $45^{\circ}$ angle cut. Measurements at each plot required two people, one counting and the other recording, and involved approximately two hours/plot. In total, 118 plots were examined.

The mean number of hare- and moose-browsed twigs per plant that possessed utilizable twigs (twigs within $2.8-\mathrm{m}$ of the ground) at each study site were considered estimates of population density. Browsed twigs can be used as a population estimate given that population members consume a relatively constant number of twigs per time period. Certainly, there is variation in per capita twig consumption but such variability is probably small. Twigs are a better item to count for food utilization since they are more apparent, less-ephemeral and easier to count than removed leaves or forbs. Twig counts do not provide an annual population estimate for moose or hare since browsed twigs persist for as long as ten years after consumption ( $\bar{x}=7.75$ years). Therefore, the twig utilization measurement is a summation of consumption over the expected life of consumed twig stubs, but it is based on the same time period for both moose and hare.

The g-dry wt $/ \mathrm{m}^{2}$ of twig production per annum within $2.8 \mathrm{-m}$ of the ground for each forest type (Botkin and Jordan, unpubl. data) was divided by the mean number of plants per $\mathrm{m}^{2}$ with usable twigs. This provides an estimate of twig production per plant; the same denominator was used for herbivore population density (twigs removed/ plant $/ \mathrm{m}^{2}$ ).

To determine moose and hare carrying capacities, the allopatric twig consumptions by moose and hare were correlated with the twig production/plant. There was no difficulty in finding areas on Isle Royale where moose were naturally allopatric, because it appeared that certain sites did not have hare or they were at such low numbers as to be nonexistent perhaps because of a lack of cover from predators. However, no naturally occurring allopatric sites could be found for hare. Consequently, exclosures which kept moose but not hare out were employed. The exclosures had been built during the 1950's at Isle Royale by L.W. Krefting and each encompasses approximately $0.25 \mathrm{hec}-$ tares. A hare population cannot be maintained exclusively in a 0.25 -ha area, but their utilization of twigs in the absence of moose is what is important. Two exclosures, one in the Washington Creek drainage and another near Siskiwit Bay, were used to determine hare consumption of twigs when protected from moose consumption.

\section{Modelling}

With the carrying capacity equations and twig production estimates for each study site, the number of twigs consumed by each species given no competition (carrying capacity, $K$ ) can be estimated. With $K$ and the observed densities of twigs removed by moose, $F_{M}$, and hare, $F_{H}$, non-linear regressions are used to determine which model of competitive mechanisms might explain observed twig use. Four models presented by Schoener (1973, 1974a, 1976, 1978) and converted to units equivalent to $K, F_{M}$ and $F_{H}$ are fit to the data. This conversion simply requires substituting into the equilibrium solutions the values of $F_{M} / C_{M}$ and $F_{H} /$ $C_{H}$ for the densities of moose and hare individuals, respectively $N_{M}$ and $N_{H}$ in Schoener's $(1973,1974 \mathrm{a}, 1976,1978)$ notation, where $C_{M}$ and $C_{H}$ are the moose and hare consumption of twigs/individual/unit time, respectively. The $C_{M}$ and $C_{H}$ terms by definition must equal Schoener's $(1973,1974 \mathrm{a}, 1976,1978) C_{M}$ and $C_{H}$ terms at equilibrium since intake at $d N / d t=0$ must satisfy per capita requirements for maintenance and replacement reproduction (see Appendix for an example of how these equations are derived). The four converted competition models are:

1) intraspecific interference with a fixed energy input:

$F_{M}=\frac{k_{7}+\left[k_{7}^{2}+4\left(K_{M}-c_{5}\right) k_{8}\right]^{0.5}}{2}$,

$F_{H}=\frac{k_{8}+\left[k_{8}^{2}+4\left(K_{H}-c_{6}\right) k_{8}\right]^{0.5}}{2}$.

2) exploitation competition with a fixed energy input or interference with a time limitation, both of which provide the Lotka-Volterra model:

$F_{M}=K_{M}-k_{1} F_{H}-c_{1}$, $F_{H}=K_{H}-k_{2} F_{M}-c_{2}$.

3) interference with fixed energy inputs:

$F_{M}=\left(K_{M}-c_{3}\right) / k_{3}+k_{4} F_{H}$,

$F_{H}=\left(K_{H}-c_{4}\right) / k_{5}+k_{6} F_{M}$, and

4) exploitation with partially overlapping resources and a fixed energy input:

$$
\begin{aligned}
& F_{M}= \frac{\left(\begin{array}{c}
\left(K_{M}-k_{9} F_{H}-c_{7}\right)+\left[\left(K_{M}-k_{9} F_{H}-c_{7}\right)^{2}\right. \\
+\left(4 k_{9} k_{10}\left(K_{M}-c_{7}\right) F_{H}\right]^{0.5}
\end{array}\right.}{2} \\
& F_{H}=\frac{\begin{array}{c}
\left(K_{H}-k_{11} F_{M}-c_{8}\right)+\left[\left(K_{H}-k_{11} F_{M}-c_{8}\right)^{2}\right. \\
\left.+\left(4 k_{11} k_{12}\left(K_{H}-c_{8}\right) F_{M}\right)\right]^{0.5}
\end{array}}{2}
\end{aligned}
$$

All $k$ 's in the above equations refer to constants. The $c$ values can be considered slack variables serving two pur- 


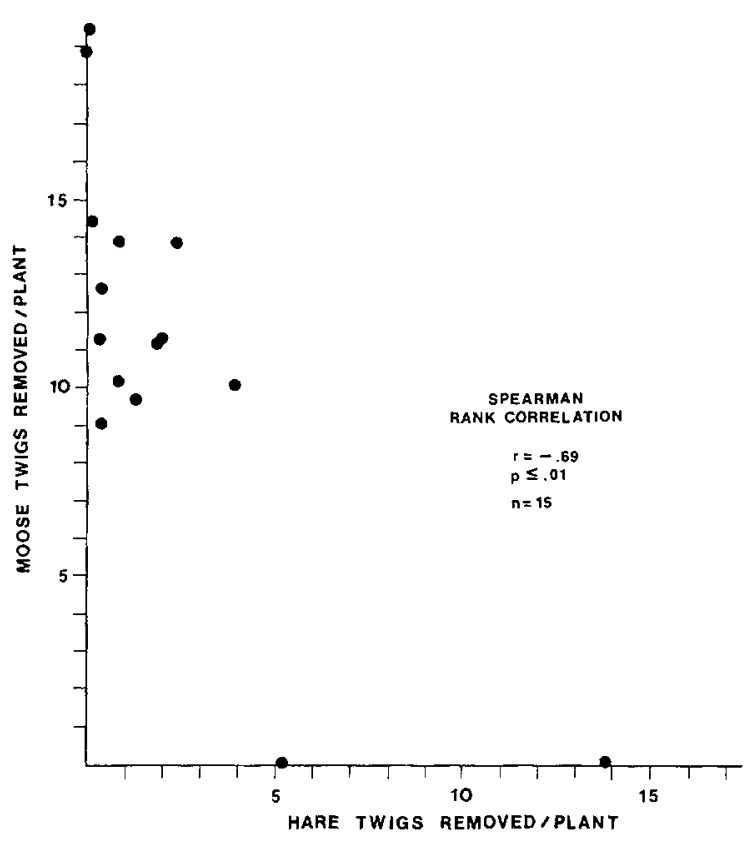

Fig. 1. A plot of hare densities versus moose densities (twigs removed/plant) indicates that there is a significant negative relationship between these values, suggesting the potential for competition

poses. First, they can modify the carrying capacity equations based on allopatric utilization to compensate for sampling error or small sample sizes. This is particularly important for hare since their carrying capacity equations are based upon very limited allopatric area and a small sample size. Second, the $c$ values can modify the competition functions at low moose or hare densities to account for a consumer's inability to use all available resources at low population densities because of satiation (Schoener 1978).

Each of the four models are fit to the data using the program RAPE (Regression Analysis Program for Economists) available at the Harvard-MIT computing facilities (Raduchel 1970). The program first attempts to minimize the sum of squared residuals by Gaussian elimination; if that is not possible then a convergence criteria for the residual sum of squares is applied ( 0.01 difference). Even when a minimum for the sum of squared residuals is achieved by the above criteria, several additional runs with different initial parameter estimates must be made to maximize the chance that a global rather than a local minimum is found. In order to start the search for a solution, initial estimates for constants are made from intuitive estimates arising from field experience. The solution provides the best leastsquares estimates for $k$ and $c$ values.

\section{Results}

The allopatric and sympatric utilization of twigs by moose and hare appears in Fig. 1. It is apparent from the plot that a negative relationship exists (Spearman Rank Correlation: $r=-0.69, P<0.01$ ) between moose and hare utilization, suggesting potential competition.

Data from each study site were divided between plots whose usable plant composition is predominantly coniferous ( $>50 \%$ conifer cover) or deciduous $(\geqq 50 \%$ deciduous cover), to ascertain whether competition differs between these habitat types. Tables 1, 2, 3 and 4 contain the allopat-
Table 1. Deciduous and coniferous forest plots for which only twigs consumed by moose were found

\begin{tabular}{|c|c|c|c|}
\hline \multirow[t]{2}{*}{ Forest type } & \multirow{2}{*}{$\begin{array}{l}\text { No. } \\
\text { plots }\end{array}$} & \multirow{2}{*}{$\frac{\bar{x} \text { twig production }}{a}$} & \multirow{2}{*}{$\begin{array}{l}\bar{x} \text { No. twigs } \\
\text { consumed by } \\
\text { moose/plot }\end{array}$} \\
\hline & & & \\
\hline \multicolumn{4}{|l|}{ Deciduous } \\
\hline West. Sub-Coastal & 1 & 7.54 & 17.79 \\
\hline Birch-Aspen & 5 & 7.41 & 15.12 \\
\hline Coastal & 1 & 1.01 & 3.66 \\
\hline Birch-Aspen & 5 & 3.77 & 9.16 \\
\hline West. Sub-Coastal & 7 & 3.90 & 13.75 \\
\hline Burn & 3 & 5.91 & 15.27 \\
\hline \multicolumn{4}{|l|}{ Coniferous } \\
\hline Aspen & 2 & 3.33 & 11.57 \\
\hline East. Sub-Coastal & 1 & 6.33 & 7.89 \\
\hline East. Coastal & 1 & 1.73 & 23.58 \\
\hline Malone & 1 & 6.85 & 10.62 \\
\hline
\end{tabular}

a Twig production $\left(\mathrm{g} / \mathrm{m}^{2}\right)$ from Botkin and Jordan, unpubl. data

Table 2. Deciduous and coniferous forest plots for which only twigs consumed by hare were found

\begin{tabular}{|c|c|c|c|}
\hline \multirow[t]{2}{*}{ Forest type } & \multirow{2}{*}{$\begin{array}{l}\text { No. } \\
\text { plots }\end{array}$} & \multirow{2}{*}{$\frac{\hat{x} \text { twig production }^{8}}{\bar{x} \text { No. plants/plot }}$} & \multirow{2}{*}{$\begin{array}{l}\bar{x} \text { No. twigs } \\
\text { consumed by } \\
\text { hare/plot }\end{array}$} \\
\hline & & & \\
\hline \multicolumn{4}{|l|}{ Deciduous } \\
\hline Burn & 1 & 3.12 & 5.15 \\
\hline Burn & 1 & 2.73 & 10.94 \\
\hline Burn & 1 & 14.58 & 31.33 \\
\hline Burn & 1 & 0.64 & 7.87 \\
\hline \multicolumn{4}{|l|}{ Coniferous } \\
\hline West. Sub-Coastal & 1 & 3.23 & 5.67 \\
\hline West. Sub-Coastal & 1 & 3.23 & 6.66 \\
\hline West. Sub-Coastal & 1 & 3.87 & 4.88 \\
\hline West. Sub-Coastal & 1 & 4.84 & 3.03 \\
\hline
\end{tabular}

a Twig production $\left(\mathrm{g} / \mathrm{m}^{2}\right)$ from Botkin and Jordan, unpubl. data

Table 3. Deciduous and coniferous forest plots from an off-lying archipelago for which twigs consumed by moose and hare were found

\begin{tabular}{|c|c|c|c|c|}
\hline \multirow[t]{2}{*}{ Area - Island ${ }^{\text {b }}$} & \multirow[t]{2}{*}{$\begin{array}{l}\text { No. } \\
\text { plots }\end{array}$} & \multirow{2}{*}{$\frac{\bar{x} \text { twig production }}{\bar{x} \text { No. plants/plot }}$} & \multicolumn{2}{|c|}{$\begin{array}{l}\bar{x} \text { No. twigs } \\
\text { consumed/plot }\end{array}$} \\
\hline & & & Hare & Moose \\
\hline \multicolumn{5}{|l|}{ Deciduous } \\
\hline $\begin{array}{l}\text { Washington } \\
\text { Booth } \\
\text { Grace } \\
\text { Isle Royale-Coastal }\end{array}$ & $\begin{array}{l}6 \\
7 \\
5 \\
1\end{array}$ & $\begin{array}{l}4.14 \\
6.27 \\
2.61 \\
6.26\end{array}$ & $\begin{array}{l}6.9 \\
1.9 \\
0.8 \\
0.004\end{array}$ & $\begin{array}{r}9.1 \\
14.9 \\
11.5 \\
14.8\end{array}$ \\
\hline \multicolumn{5}{|l|}{ Coniferous } \\
\hline $\begin{array}{l}\text { Washington } \\
\text { Booth } \\
\text { Grace } \\
\text { Isle Royale-Coastal }\end{array}$ & $\begin{array}{l}4 \\
3 \\
5 \\
3\end{array}$ & $\begin{array}{l}3.23 \\
6.29 \\
1.89 \\
4.08\end{array}$ & $\begin{array}{l}1.5 \\
2.8 \\
1.1 \\
0.4\end{array}$ & $\begin{array}{r}11.9 \\
3.1 \\
16.3 \\
13.8\end{array}$ \\
\hline
\end{tabular}

a Twig production $\left(\mathrm{g} / \mathrm{m}^{2}\right)$ from Botkin and Jordan, unpubl. data

b Islands listed according to decreasing distance from nearest point of main island 
Table 4. Deciduous and coniferous forest plots from the main island for which twigs consumed by moose and hare were found

\begin{tabular}{|c|c|c|c|c|}
\hline \multirow[t]{2}{*}{ Forest type } & \multirow[t]{2}{*}{$\begin{array}{l}\text { No. } \\
\text { plots }\end{array}$} & \multirow{2}{*}{$\frac{\bar{x} \text { twig production }}{{ }^{a}}$} & \multicolumn{2}{|c|}{$\begin{array}{l}\bar{x} \text { No. twigs } \\
\text { consumed/plot }\end{array}$} \\
\hline & & & Hare & Moose \\
\hline \multicolumn{5}{|l|}{ Deciduous } \\
\hline Yellow Birch & 8 & 3.52 & 0.95 & 9.1 \\
\hline West. Sub-Coastal & 1 & 6.26 & 0.004 & 14.8 \\
\hline West. Sub-Coastal & 4 & 3.39 & 0.39 & 9.3 \\
\hline Scrub-Burn & 5 & 8.42 & 0.02 & 19.3 \\
\hline Burn & 5 & 8.25 & 0.02 & 19.5 \\
\hline Sugar Maple & 5 & 5.53 & 0.15 & 12.6 \\
\hline East. Sub-Coastal & 5 & 3.96 & 1.26 & 9.4 \\
\hline Yellow Birch & 6 & 3.39 & 0.85 & 9.0 \\
\hline Yellow Birch & 14 & 3.52 & 0.97 & 9.0 \\
\hline \multicolumn{5}{|l|}{ Coniferous } \\
\hline Coastal & 3 & 4.08 & 0.40 & 13.8 \\
\hline Yellow Birch & 2 & 4.20 & 4.20 & 10.8 \\
\hline West. Sub-Coastal & 3 & 5.29 & 0.19 & 12.0 \\
\hline Yellow Birch & 4 & 3.98 & 0.71 & 12.5 \\
\hline Yellow Birch & 6 & 2.78 & 3.60 & 12.6 \\
\hline
\end{tabular}

a Twig production $\left(\mathrm{g} / \mathrm{m}^{2}\right)$ from Botkin and Jordan, unpubl. data

Table 5. Carrying capacity for moose and hare in deciduous and coniferous forests (Tables 1 and 2), where $\mathrm{P}$ is $\mathrm{g}$ of twig/plant

\begin{tabular}{llll}
\hline $\begin{array}{l}\text { Moose } \\
\text { Deciduous }\end{array}$ & $K_{M}=3.10+1.90(\mathrm{P})$ & $r^{2}=0.86$ & $n=6$ \\
$\quad$ Coniferous & $K_{M}=24.29-2.38(\mathrm{P})$ & $r^{2}=0.70$ & $n=4$ \\
Hare & & & \\
Deciduous & $K_{H}=4.25+1.82(\mathrm{P})$ & $r^{2}=0.92$ & $n=4$ \\
Coniferous & $K_{H}=12.45-1.95(\mathrm{P})$ & $r^{2}=0.93$ & $n=4$ \\
\hline
\end{tabular}

Table 6. Parameters computed for different forms of competition isoclines (Schoener 1974a, 1976) using the data for moose and hare on the archipelago (Table 3 ). The parameters were only computed for hare since the numbers of moose are limited by their ability to swim to these small islands as well as by food availability

\begin{tabular}{|c|c|c|c|c|c|c|}
\hline \multirow[t]{2}{*}{ Competition } & \multicolumn{2}{|l|}{$r^{2}$} & \multicolumn{2}{|c|}{ Residuals $^{2}$} & \multicolumn{2}{|l|}{$N$} \\
\hline & $\begin{array}{l}\text { Decid- } \\
\text { uous }\end{array}$ & $\begin{array}{l}\text { Conif- } \\
\text { erous }\end{array}$ & $\begin{array}{l}\text { Decid- } \\
\text { uous }\end{array}$ & $\begin{array}{l}\text { Conif- } \\
\text { erous }\end{array}$ & $\begin{array}{l}\text { Decid- } \\
\text { uous }\end{array}$ & $\begin{array}{l}\text { Conif- } \\
\text { erous }\end{array}$ \\
\hline ecific & 0.03 & 0 & 29.75 & 4.17 & 4 & 4 \\
\hline Interspecific & 0.85 & 0 & 4.28 & 25.03 & 4 & 4 \\
\hline Lotka-Volterra & 0.93 & $0.83^{\mathrm{a}}$ & 2.08 & 1.32 & 4 & 4 \\
\hline Exploitative & $0.94 * * \mathrm{a}$ & 0.64 & 1.87 & 1.94 & 4 & 4 \\
\hline
\end{tabular}

** $P<0.05$

$\approx$ Best fit

ric and sympatric data on moose and hare twig use, which combined with the carrying capacity equations (Table 5) can be used to solve the non-linear regressions for each of the four competitive models. Tables 6 and 7 present the coefficients of determination $\left(r^{2}\right)$ and the sum of squared residuals for each model. Results show that the exploitation model with exclusive and overlapping resources generally gives the best fit to the observed data. Five of six sets of densities fit the exploitative model with
Table 7. Parameters computed for different forms of competition isoclines (Schoener 1974a, 1976) using the data for moose and hare on the mainland (Table 4)

\begin{tabular}{|c|c|c|c|c|c|c|}
\hline \multirow[t]{2}{*}{ Competition } & \multicolumn{2}{|l|}{$r^{2}$} & \multicolumn{2}{|c|}{ Residuals $^{2}$} & \multirow{2}{*}{$\frac{N}{\begin{array}{l}\text { Decid- } \\
\text { uous }\end{array}}$} & \multirow[b]{2}{*}{$\begin{array}{l}\text { Conif- } \\
\text { erous }\end{array}$} \\
\hline & $\begin{array}{l}\text { Decid- } \\
\text { uous }\end{array}$ & $\begin{array}{l}\text { Conif- } \\
\text { erous }\end{array}$ & $\begin{array}{l}\text { Decid- } \\
\text { uous }\end{array}$ & $\begin{array}{l}\text { Conif- } \\
\text { erous }\end{array}$ & & \\
\hline \multicolumn{7}{|l|}{ Moose } \\
\hline Intraspecific & $0.94 * *$ & 0.64 & 7.19 & 2.15 & 9 & 5 \\
\hline Interspecific & $0.97^{* *}$ & 0.37 & 0.96 & 2.93 & 9 & 5 \\
\hline Lotka-Volterra & $0.96 * *$ & 0.50 & 1.22 & 2.30 & 9 & 5 \\
\hline Exploitative & $0.99 * * a$ & $0.72^{a}$ & 0.66 & 1.26 & 9 & 5 \\
\hline
\end{tabular}

$\begin{array}{lllrrrr}\text { Hare } & & & & & & \\ \text { Intraspecific } & 0 & 0.02 & 16.51 & 14.24 & 9 & 5 \\ \text { Interspecific } & 0 & 0.63 & 105.82 & 3.98 & 9 & 5 \\ \text { Lotka-Volterra } & 0.70 & 0.91 & 1.02 & 1.36 & 9 & 5 \\ \text { Exploitative } & 0.99^{* * a} & 0.93^{* * a} & \begin{array}{c}0.17 \\ \times 10^{-3}\end{array} & 0.06 & 9 & 5 \\ & & & & & \end{array}$

${ }^{* *} P<0.05$

a Best fit

Table 8. Exploitative competition isoclines computed by non-linear regression analysis and the revised carrying capacity equations (see text)

\begin{tabular}{|c|c|}
\hline \multicolumn{2}{|c|}{ Mainland deciduous } \\
\hline Moose: & $M=0.5\left[\left(K_{M}-28.59 H\right)\right.$ \\
\hline \multirow{3}{*}{ Hare: } & $\begin{aligned} & +\sqrt{\left.\left(K_{M}-28.59 H\right)^{2}+101.65 K_{M} H\right]} \\
K_{M}=3.10 & +1.90(\mathrm{P})\end{aligned}$ \\
\hline & $H=0.5\left[\left(K_{H}-1.80 M\right)\right.$ \\
\hline & $\begin{array}{c}+\sqrt{\left.\left(K_{H}-1.80 M\right)^{2}+0.0006 K_{H} M\right]} \\
K_{H}=10.85+1.82(\mathrm{P})\end{array}$ \\
\hline \multicolumn{2}{|c|}{ Mainland coniferous } \\
\hline \multirow[t]{2}{*}{ Moose: } & $M=0.5\left[\left(K_{M}-10.49 H\right)\right.$ \\
\hline & $\begin{aligned} &+\sqrt{\left.\left(K_{M}-10.49 H\right)^{2}+28.89 K_{M} H\right]} \\
& K_{M}=24.29-2.38(\mathrm{P})\end{aligned}$ \\
\hline \multirow[t]{2}{*}{ Hare: } & $H=0.5\left[\left(K_{H}-2.52 M\right)\right.$ \\
\hline & $\begin{aligned} &+\sqrt{\left.\left(K_{H}-2.52 M\right)^{2}+0.007 K_{H} M\right]} \\
& K_{H}=39.06-1.95(\mathrm{P})\end{aligned}$ \\
\hline \multicolumn{2}{|l|}{ Island hare } \\
\hline \multirow[t]{2}{*}{ Deciduous: } & $M=0.5\left[\left(K_{H}-2.50 M\right)\right.$ \\
\hline & $\begin{aligned} &+\sqrt{\left.\left(K_{H}-2.50 M\right)^{2}+0.0361 K_{H} M\right]} \\
& K_{H}=21.77+1.82(\mathrm{P})\end{aligned}$ \\
\hline \multirow[t]{2}{*}{ Coniferous: } & $M=0.5\left[\left(K_{\underline{H}}-0.72 M\right)\right.$ \\
\hline & $\begin{aligned} &+\sqrt{\left.\left(K_{H}-0.72 M\right)^{2}+0.24 K_{H} M\right]} \\
& K_{H}=12.45-1.95(\mathrm{P})\end{aligned}$ \\
\hline
\end{tabular}

exclusive and overlapping resources best (binomial probability: $P<0.06$ ); the Lotka-Volterra model is second with one of six sets.

Comparison of the $r^{2}$ and sum of squared residuals for the exploitative model with exclusive and overlapping resources and the Lotka-Volterra model is complicated since the number of parameters fit by regression analysis is not equal in the two models: 3 and 2, respectively. In addition, the Lotka-Volterra model with 2 parameters will always be 
at a global minimum sum of squared residuals because the solution can be achieved by Gaussian elimination, while the 3 parameter model will have only an estimate of minimum sum of squared residuals that is always larger than the true minimum. Using the techniques developed by Mueller and Ayala (1982) for comparing 2 and 3 parameter models, the 3 parameter exploitation model was found to provide a better fit to the data. Finally, the Lotka-Volterra model in many instances provides unrealistic competitive results (see below), while the exploitation model with exclusive and shared resources does not.

The isocline equations for the exploitative model with shared and exclusive resources are presented in Table 8. Carrying capacity modifications ( $c$, slack variables) are only found to be important for hare, as expected due to their limited allopatric data.

\section{Discussion}

How might moose and hare compete in each of the mechanistic ways hypothesized by Schoener (1973, 1974a, 1976, 1978) and tested here? Model 1 for intraspecific competition for a fixed energy input would arise if moose and hare did not compete at all, whether by interference or exploitation. Model 2, Lotka-Volterra competition, arises by exploitation of a limiting resource shared completely by both species or by interference competition that limits feeding time. Exploitation of a resource completely shared by moose and hare might occur for food; but, as Schoener (1974a) demonstrates, this form of competition guarantees the trivial and unobserved result of competitive exclusion.

Interference between moose and hare might occur in several ways: agonistic interactions or indirect modification of the environment for each species by the other in a negative manner. No incidence of moose or hare chasing the other off was observed or reported in the literature. Moose might deleteriously modify the environment for hare by opening the forest canopy, such that hare are more susceptible to predation, either leading to greater mortality or to a reduction in feeding time to avoid predator exposure. This is unlikely since a dichotomy would have been observed between the mainland with predators and the islands without predators. Finally, moose and hare might decrease canopy cover modifying the thermal environment and reducing their foraging time (Belovsky, 1981, in press). This is unlikely because very little dense canopy is needed for cover and the more open forest is where both species prefer to feed (Belovsky, 1981, in press). All of these potentials for interference competition also apply to Model 3 where interference impacts upon individual energy demands for each species rather than the time for resource acquisition.

If, as indicated by this study, moose and hare exploitatively compete for a resource that is partially shared, what is the resource and how is it partitioned between shared and exclusive components? The most obvious resource commonly used by moose and hare is the vegetation for food. Twigs, winter food, in particular may be the resource for which moose and hare compete, since twigs are scarcer in winter. Food is reported as a potentially limiting resource for moose (Peek 1982) and hare (Bittner and Rongstad 1982).

The most obvious way of partitioning vegetation would be by height above the ground for two herbivores as dissimilar in size as moose and hare, since hare should consume
Table 9. Parameters used in computing the amount of exclusive and overlapping resources for hare and moose

\begin{tabular}{|c|c|c|}
\hline & Hare & Moose \\
\hline Weight $(\mathrm{kg})$ & 1.5 & 358.0 \\
\hline Metabolism $(\mathrm{kcal} / \text { day })^{\mathrm{a}}$ & 230.8 & $11,522.3$ \\
\hline Stomach capacity (g-wet wt) ${ }^{b}$ & 179.5 & $32,900.0$ \\
\hline $\begin{array}{l}\text { Flow rate of food (no. of times the } \\
\text { stomach contents turn over/day) }\end{array}$ & 3.0 & 0.5 \\
\hline Daily feeding time $(\mathrm{min})^{\mathrm{c}}$ & 202.8 & 590.0 \\
\hline $\begin{array}{l}\text { Maximum cropping rate } \\
\text { (twigs } / \text { min) }^{\mathbf{c}}\end{array}$ & 8.3 & 25.0 \\
\hline Twig sizes (min-max) $\mathrm{mm}^{\mathrm{c}}$ & $1.3-4.3$ & $1.33-6.20$ \\
\hline Bulk of food (g-wet/g-dry) ${ }^{c}$ & 2.12 & 2.00 \\
\hline $\begin{array}{l}\text { Minimum digestibility }{ }^{\mathrm{C}} \\
(\% \text { mineral }+ \text { protein })\end{array}$ & 10.3 & 7.3 \\
\hline Energy content (kcal/g-dry wt) ${ }^{d}$ & 4.2 & 4.2 \\
\hline $\begin{array}{l}\text { Available in environment }:^{\mathrm{c}} \\
\text { Mineral + protein - Deciduous } \\
\quad-\text { Coniferous } \\
\text { Twig diameters (mm) }\end{array}$ & $\begin{aligned} & 5.2-12.3 \\
& 5.2-15.9 \\
\sim & 0-7.6\end{aligned}$ & $\begin{aligned} & 5.2-12.3 \\
& 5.2-15.9 \\
\sim & 0-7.6\end{aligned}$ \\
\hline \multicolumn{3}{|c|}{$\begin{array}{l}\text { Metabolism }=140 \mathrm{~W}_{\mathbf{k g}}^{0.75} \text {; Kleiber } 1961 \text {; Moen } 1973 \\
\text { Computed from body weight stomach regressions in Belovsky } \\
(1978 \text {, in press) } \\
\text { d Gelovsky } 1981 \text {, in press } \\
\text { Golley } 1961\end{array}$} \\
\hline
\end{tabular}

low vegetation, and moose higher vegetation, with a region of overlap. This simple explanation is totally inadequate since moose and hare consume vegetation that is $91 \%$ similar by height in summer and winter (\% similarity, Schoener 1970: 465 hare food items and 2,941 moose food items). Partitioning by height may occur in other regions, but Telfer (1972) also reports similar overlap in feeding height between moose and snowshoe hare. Height may not serve as a means of partitioning food for several reasons. First, moose and hare twig use in winter by height is moderated by snowfall with hare capable of walking on top of the snow and moose capable of breaking through the crust. Second, both moose and hare prefer more nutritious plants (Belovsky, 1981, in press), which often are younger and consequently lower to the ground and in reach of both herbivores.

Belovsky (1981, in press) found that moose and hare appear to select food items on the basis of a minimum quality and item size to satisfy time-energy requirements. These minimum requirements differ for moose and hare (Table 9) and this might explain the partitioning of food resources. The foraging model developed by Belovsky (1981, in press) to predict diet selection on the basis of satisfaction of minimum quality and item size can be written as:

$D \geqq \frac{(M)(B)}{(S)(F)(E)}$,

where $D$ is the minimum percent dry matter digestibility of food consumed, $M$ is the energy requirements of the animal (kcal/day), $B$ is food bulk (wet to dry weight), $S$ is stomach capacity, $F$ is the number of times each day the stomach contents turn over, and $E$ is the gross caloric content of the food; and 
$I \geqq \frac{M}{(E)(C)(D)(T)}$,

where $I$ is the minimum weight of a food item consumed, $C$ is the cropping rate of food items (items/time) and $T$ is the maximum amount of time per day the animal has to feed. $D$ can be converted into $Q$, the mineral + protein content of plants, given a regression of data on digestion versus mineral + protein composition of the foods (moose, Belovsky 1981; and hare, Belovsky, in press). Equation 2 can be used to compute a minimum twig size required by hare and moose, but for winter feeding there also exists a maximum twig size which can be eaten (Belovsky, 1981, in press). The maximum twig size appears to be set by the strength of the wood relative to the animal's ability to shear with its teeth; the mean of the largest $10 \%$ of twigs observed to be eaten was used in lieu of an a priori estimate. Using each species' $Q$ and $I$ values, and the available ranges of $Q$ and $I$ values in the environment, the amount of overlapping and total food resources for each species can be computed.

Using the data presented in Table 9, a graphical solution (Fig. 2) of moose and hare twig utilization can be constructed. Table 10 presents the percentages of exclusive resources predicted by the model and those estimated from the regression analysis $\left(K_{10} / K_{9}\right.$ and $\left.K_{11} / K_{12}\right)$. The comparison indicates a good agreement $\left(r^{2}=0.99, P<0.01\right)$. Given resource utilization as depicted in Fig. 2, a direct computation of the competition parameters in Schoener's (1974a, 1975) utilization model can be made:

$K_{9}=\left(q_{H} / q_{M}\right)\left(d A_{M} / A_{H}\right)$,

and

$K_{11}=\left(q_{M} / q_{H}\right)\left(d A_{M} / A_{H}\right)$

where $K_{9}$ is the impact of hare on moose and $K_{11}$ is the impact of moose on hare for shared resources. $q_{H}$ and $q_{M}$ are the proportion of resources shared by hare and moose, $d$ is the observed number of hare twigs removed for each moose twig, and $A_{M}$ and $A_{H}$ are the total resource areas (Fig. 2) available to moose and hare (see Appendix for derivation of the competition parameters). Hare generally eat only terminal buds and adjacent new growth, but a moose removes more of the older twig. A hare's twig consumption leaves a remainder too small to satisfy a moose's timeenergy budget, but a moose on average takes two terminal buds with its twig, giving a value of 2 for $b$. The computed competition parameters appear in Table 10 and are very similar to the regression estimates $\left(r^{2}=0.99, P<0.01\right)$.

The close agreement between predicted and observed proportions of shared and exclusive resources indicates the utility of incorporating foraging models with mechanistic models of competition. The combination of these models may not lead to elegant theoretical models that are analytically tractable (e.g. Tilman 1982), but they are biologically satisfying. Finally, despite the great effort expended by ecologists in predicting competition coefficients (Horn 1966; Levins 1968; Colwell and Fatuyma 1971; Pianka 1973, 1974, 1975; Schoener 1974b, May 1975), and despite some of the inherent errors and modifications (Schoener 1974b; Hurlbert 1978; Abrams 1980 b), these measures of potential competition coefficients are limited to the subset of mechanistic models that result in linear isoclines, as characterized by the Lotka-Volterra competition model. Indeed, Abrams

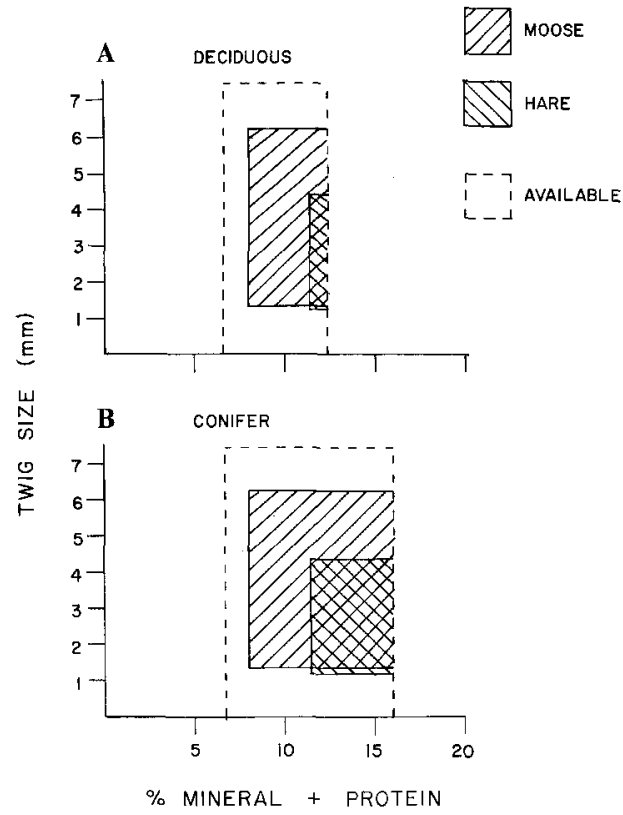

Fig. 2 A, B. The plot of overlap in the use of plant foods by their quality (\% mineral + protein) and item size ( $\mathrm{mm}$ twig diameter) between moose and hare in deciduous (A) and coniferous (B) forest

Table 10. The regression estimated and a priori model estimates for the amount of exclusive resource possessed by hare and moose in each habitat and the competitive effect of one species upon the other

\begin{tabular}{lcc}
\hline & $\begin{array}{l}\text { Regression } \\
\text { estimate }\end{array}$ & $\begin{array}{l}\text { Model } \\
\text { estimate }\end{array}$ \\
\hline $\begin{array}{l}\text { \% of available resource } \\
\text { that is exclusive: }\end{array}$ & \\
Moose in deciduous & 88.9 & 75.6 \\
Moose in coniferous & 68.9 & 60.3 \\
Hare in deciduous & $0.2^{\mathrm{a}}$ & 1.0 \\
Hare in coniferous & $4.2^{\mathrm{a}}$ & 1.0 \\
Competition effect & & \\
of other species on: & & \\
Moose in deciduous & 28.59 & 32.92 \\
Moose in coniferous & 10.49 & 12.44 \\
Hare in deciduous & $2.15^{\mathrm{a}}$ & 2.00 \\
Hare in coniferous & $1.62^{\mathrm{a}}$ & 2.00 \\
\hline
\end{tabular}

a Mean of hare values computed for the off-lying and main island areas

(1980a) has pointed out that the conditions for constant competition coefficients as assumed in these formulations are unlikely. Finally, application of these estimates of competition coefficients to the data collected at each site in this study and their incorporation into the Lotka-Volterra model, as an approximate representation of competition, leads to totally unrealistic results ranging from competitive exclusion and unstable coexistence to stable coexistence, when at each study site stable coexistence is observed.

The mechanistic model of competition for exploitation of shared and exclusive resources combined with the foraging model leads to assymetries in the competition between moose and hare. The isocline equations (Table 8) can be solved to determine which of the two species consumes 


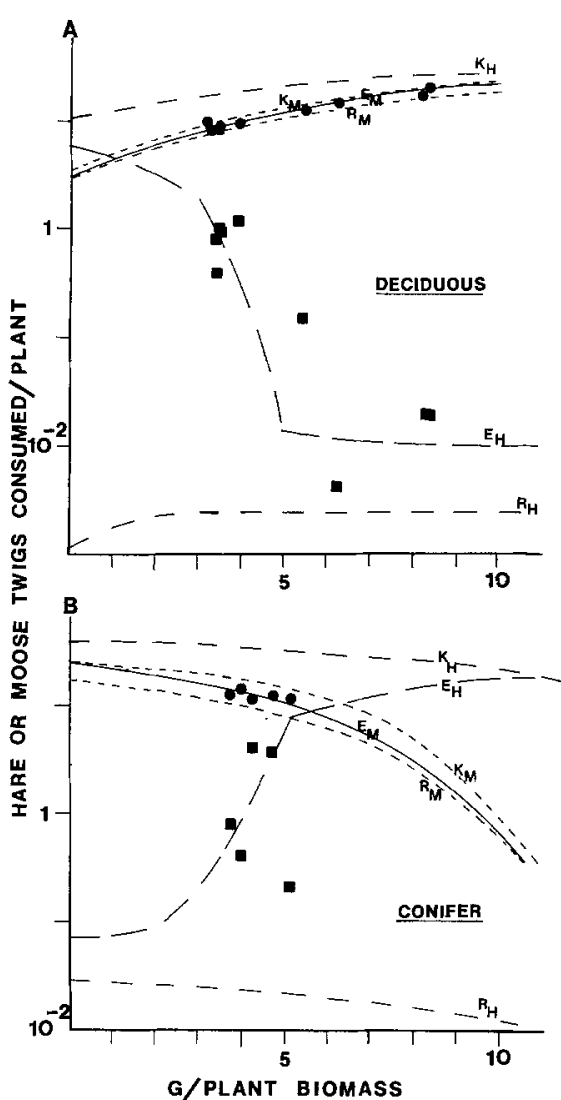

Fig. 3 A, B. Plots of the predicted carrying capacities $\left(K_{*}\right)$, amount of exclusive resource $\left(R_{*}\right)$ and the competitive equilibrium density $\left(E_{*}\right)$ for moose $(M)$ and hare $(H)$ are presented over a range of site primary productivities $(\mathrm{g} / \mathrm{plant})$ within the reach of the two species. These values are presented for two habitat types: deciduous forest (A) and coniferous forest (B), and are compared with ob-

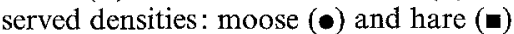

more available twigs at different twig production levels. In the deciduous habitat, hare consume more twigs at productivities $\left(\bar{x} \mathrm{~g} / \mathrm{m}^{2}\right) /\left(\bar{x}\right.$ plants $\left./ \mathrm{m}^{2}\right)$ less than 1.25 -g/plant and in the coniferous habitat at values greater than 5.50. At other values, moose consume more twigs.

The differences in utilization between moose and hare arise for two reasons: changes in carrying capacity and competitive ability with variation in standing crop of food. In the deciduous forest carrying capacity increases with twig biomass, while the reverse is found for coniferous sites. Furthermore, the moose's carrying capacity changes much more than the hare's with twig biomass. This arises since small animals with their smaller metabolic demands will be less impacted by declines in food abundance (Schoener 1971; Belovsky 1978). Carrying capacity, in addition, may decline in coniferous areas with increasing twig biomass because the animals may not be able to move freely through thick conifer vegetation (this would especially be true for the larger herbivores, the moose) or because of declining plant quality in the heavy shade.

Relative competitive success changes with forest type and productivity because the equilibrium solution to the competition model (Model 4) depends on carrying capacity values. This can be assessed by comparing each species' predicted consumption with competition, $F_{*}$, against its allopatric consumption, $I_{*}$, and its exclusive resource availability, $R_{*}$. Plots of $F_{*}, R_{*}$ and $K_{*}$ in each habitat type are presented in Fig. 3.
Moose twig consumption in deciduous areas approaches the exclusive resource values, $R_{M}$, at low twig biomass and increases towards the carrying capacity, $I_{M}$, as biomass increases (Fig. 3 a). Hare consumption follows a reverse pattern; however, the decline of hare consumption towards the exclusive value, $R_{H}$, with increasing biomass is very rapid (Fig. $3 \mathrm{a}$ ). In coniferous areas (Fig. $3 \mathrm{~b}$ ), the same patterns emerge for moose and hare except biomass effects are reversed: i.e. moose approach $R_{M}$ at high biomass and hare approach their $R_{H}$ at low values. These results indicate that hare are extremely susceptible to competition from moose, while moose are only slightly impacted.

Hare consumption in the presence of moose is predicted by the model to decrease in deciduous areas while consumption in coniferous areas increases as observed twig biomass increases (Fig. 2). This indicates habitat-shift by hare, since relative hare densities will become greater in coniferous areas versus deciduous areas when moose are present. Moose are predicted to show a far weaker shift, increasing their use of deciduous areas and decreasing their use of coniferous areas as biomass increases, which probably can not be detected as habitat-shift in the field. The data from this study indicates habitat shift such that as twig removal by moose in deciduous areas increases, hare use of coniferous areas within the same study site increases (rank correlation: $r=0.84, n=8, P<0.001$ ). No statistical change in moose utilization could be found.

The assymetries of competition between moose and hare also have an effect on each species' impact on forest growth. Hare are predicted by the model to have a greater effect on plant growth and survival, by clipping twigs, at low deciduous productivity and high coniferous productivity, while moose are just the opposite. Hare should never consume more deciduous biomass than moose, but at coniferous biomasses greater than 9-g/plant, hare should consume more than moose.

Twig biomass (g/plant) can be related to forest age. In early-aged stands, biomass will be low because the plants are small, while in late-aged stands, twig biomass will be high because the plants are larger. This indicates that hare should have more impact in early-aged deciduous stands and late-aged coniferous stands, while moose have the opposite effect. These variable impacts by moose or other large ungulates and hare on forest growth are borne out by a number of field studies (Aldous and Aldous 1944; Hough 1949; Krefting 1953; Dodds 1960; Bider 1961; Vozeh and Cumming 1961; Bookhout 1965a, b). The variable results reported in the above studies have been argued as to which is correct; however, the observed variation is as expected from the competition model presented in this paper.

It is known that predation can modify competitive interactions (Menge and Sutherland 1976) and predation may be complicating the population densities found in this study. Moose are preyed upon by the timber wolf (Canis lupus) at Isle Royale, but because of their size differences the wolf hunts in packs and seldom takes prime-aged adults. This suggests, along with the fact that moose numbers do not appear to be limited by predation (Mech 1974), that wolves are not an important moderator of competition by moose on hare. On the other hand, hare are preyed upon by the red fox (Vulpes vulpes) which is extremely abundant and perhaps the lynx (Lynx canadensis - the lynx may be extinct on the island), both of which are larger than hare. 
It is known that the red fox's main prey is hare, contained on the average in $25.8 \%$ of the scats (Mech 1966; Johnson 1970). Also, it is known that hare numbers and distributions can be limited by predation (Keith 1967, 1974; Keith and Surrendi 1971; Rusch et al. 1972; Brand et al. 1976; Keith and Windberg 1978).

Since hare would appear to be more influenced by predation than moose, we might expect that with predation:

1) hare will have a smaller carrying capacity, $K_{H}$, on the mainland versus the predator-free islands, since hare will not be able to use more open areas due to the greater hunting success of predators in these areas;

2) a greater proportion of hare resources will be exclusive with predators since hare will avoid the use of open areas; this provides less shared food with moose since the foods growing in open areas, although more nutritious, are generally of larger size and also can be used by moose; and

3) competitive effects of moose on hare might be greater in areas with predators since moose tend to open the habitat by their feeding, increasing the success of predators.

Out of six potential comparisons ( 3 traits above in 2 habitat types) four fit the above traits (binomial probability: $P<0.11$ ). Therefore, it is plausible, but unknown, whether predation might be enhancing the competitive impact of moose; however, food exploitation appears to be the main influence.

\section{Conclusion}

Competition between two very different-sized herbivores appears to be intense and can be explained by a model of resource (food) competition where overlapping and exclusive resources are utilized. When the competition model is fitted to field data on animal densities, the estimated competition coefficients and proportions of exclusive resources are found to agree quite well with those computed a priori, using the herbivore feeding model developed by Belovsky (1981, in press). This model predicts the minimum size and quality of plants fed upon by herbivores of different body sizes and uses this information along with the availability of plants of different sizes and qualities to ascertain which resources are exclusive and overlapping.

Acknowledgments. I thank T.W. Schoener, S.L. Lima and J.B. Slade for critically reading early drafts of this paper and supplying helpful comments. I thank J. Cannon, K. Hay, D. Johnson, D. Pletcher, J.B. Slade for their help in collecting the data, and the personnel of Isle Royale National Park for their help. The work was supported by NSF grant DEB-78-02069 A01 to the author and T.W. Schoener, and grants to the author from the Environmental Education Fund, the Harvard Society of Fellows and the Richmond Society, Harvard University.

\section{Appendix}

The model of exploitative competition and its competition parameters:

Schoener's (1974a, 1976, 1978) model of exploitative competition with exclusive and shared resources is:

$\frac{d N_{1}}{d t}=R_{1} N_{1}\left(\frac{I_{\mathrm{E} 1}}{N_{1}}+\frac{I_{01}}{N_{1}+\beta N_{2}}-C_{1}\right)$

where:
$N_{1}=$ the number of individuals of species 1

$N_{2}=$ the number of individuals of species 2

$R_{1}=$ species 1 's rate of conversion of resources into offspring

$I_{\mathbf{E} 1}=$ amount of resource that is exclusively available to species 1 per unit time

$I_{01}=$ amount of resources available to species 1 that is shared with species 2 per unit time

$C_{1}=$ species 1 's resource requirements for maintenance and replacement reproduction per unit time, and

$\beta=$ a competition parameter relating consumption by species 2 into species 1's consumption of shared resource.

The $\beta$ term can be written as:

$\beta=\frac{b M_{2}}{a M_{1}}$

where $a$ is species 1 's proportion of diet composed of shared resources, $b$ is species 2's proportion of diet composed of shared resources that is also used by species $1, M_{1}$ is species 1 's per capita resource intake per unit time and $M_{2}$ is species 2's per capita resource intake per unit time. $M_{1}$ and $M_{2}$ will vary with population densities of the species, since the resources available to each individual will be changing. Also, the expression for $\beta$ is based on two assumptions:

1) items of resources ingested by species 1 and 2 are equivalent, i.e. an item as perceived by 1 is perceived the same by 2 , and

2) the total resources available to 1 and 2 are of equal abundance, so that diet proportions $(a, b)$ reflect importance to the consumer's satisfaction of $C_{1}$. Equation (ii) with its diet proportions and intake values has many of the characteristics of Schoener's (1974b) method for estimating competition coefficients.

If we solve the competition Eq. (i) for its zero isocline, we have:

$0=N_{1}\left(I_{01}+I_{\mathrm{E} 1}-C_{1} \beta N_{2}\right)-C_{1} N_{1}^{2}+I_{\mathrm{E} 1} \beta N_{2}$,

or

$N_{1}=$

$\frac{\left.\left(K_{1}-C_{1} \beta N_{2}\right)+\left[K_{1}-C_{1} \beta N_{2}\right)^{2}+4 C_{1} e_{1} K_{1} \beta N_{2}\right]^{0.5}}{2 C_{1}}$

where $K_{1}=I_{\mathrm{E} 1}+I_{01}$, carrying capacity in allopatry, and $e_{1}=I_{\mathrm{E} 1} / K_{1}$. Now, if we substitute $N_{1}=F_{1} / M_{1}$ and $N_{2}=F_{2} /$ $M_{2}$ into Eq. (iii), where $F_{1}$ and $F_{2}$ are species 1 and 2 's total resource consumption, we obtain:

$F_{1}=$

$\frac{\left(K_{1}-\frac{C_{1} \beta F_{2}}{M_{2}}\right)+\left[\left(K_{1}-\frac{C_{1} \beta F_{2}}{M_{2}}\right)^{2}+4 C_{1} e_{1} K_{1} \beta N_{2}\right]^{0.5}}{2}$ (iv)

where $C_{1} \beta / M_{2}=K_{9}$ or $K_{11}$ and $4 C_{1} e_{1} K_{1} \beta=K_{10}$ or $K_{12}$ in the text. The $K_{9}$ and $K_{11}$ terms are the competition parameters referred to in the text and by substituting (Eq. (ii) for $\beta$, they can be written as:

$K_{9}$ or $K_{11}=\frac{C_{1} M_{2} b}{M_{2} M_{1} a}$

By definition $C_{1}$ equals $M_{1}$ at $d N_{1} / d t=0$, because per capita resource intake per unit time can only supply mainte- 
nance and replacement reproduction, $C_{1}$. Therefore, $K_{9}$ or $K_{11}$ simply equals $b / a$. The simple form of $b / a$ for the competition parameter is interesting since it is equivalent to Levins' (1968) competition coefficient estimate with only two resource classes, $I_{01}$ and $I_{\mathrm{E} 1}$.

In the moose-hare example of this type of competition presented in the text, both assumptions upon which the Eq. (ii) expression for $\beta$ is developed are violated. Moose have a greater resource availability than hare and moose consume several hare twigs by consuming one of their own twigs. Therefore, a unit of hare consumption in the region of shared resources (Fig. 3) will have a higher probability of occurring than a unit of moose consumption and will be more valuable in terms of overall resource available to a hare than a moose. Consequently, the $b / a$ term for $K_{9}$ or $K_{11}$ must be scaled by $d A_{M} / A_{H}$, where $d$ is the number of moose twigs per hare twig, $A_{M}$ is the area of total moose resources usable (Fig. 3) and $A_{H}$ is the area of total hare usable resources (Fig. 3), such that:

$K_{9}$ or $K_{11}=\frac{b}{a} \frac{A_{M}}{A_{H I}} d$

where $b$ and $a$ can be estimated as the proportions of $A_{M}$ and $A_{H}$ shared by the two species.

\section{References}

Abrams P (1980a) Are competition coefficients constant? Amer Nat 116:730-735

Abrams P (1980b) Some comments on measuring niche overlap. Ecology 61:44-49

Abrams P (1981 a) Alternative methods of measuring competition applied to two Australian hermit crabs. Oecologia (Berlin) $51: 233-239$

Abrams P (1981 b) Competition in an Indo-Pacific hermit crab community. Oecologia (Berlin) $51: 240-249$

Aldous CM, Aldous SE (1944) The snowshoe hare - serious enemy of forest plantations. Jour For 42:88-94

Ayala FJ (1971) Competition between species: frequency dependence. Science 171:820-824

Ayala FJ, Gilpin ME, Ehrenfeld JG (1973) Competition between species: theoretical models and experimental tests. Theor Pop Biol 4:331-356

Belovsky GE (1978) Diet optimization in a generalist herbivore: the moose. Theor Pop Biol 14:105-134

Belovsky GE (1981) Food plant selection by a generalist herbivore: the moose. Ecology $62: 1020-1030$

Belovsky GE (in press) Snowshoe hare optimal foraging and its implications for population dynamics. Theor Pop Biol

Belovsky GE (in prep) Herbivore body size and food competition

Belovsky GE, Jordan PA (1978) The time-energy budget of a moose. Theor Pop Biol 14:76-104

Bider JR (1961) An ecological study of the hare Lepus americanus. Can J Zool 39:81-103

Bittner SL, Rongstad OJ (1982) Snowshoe hares and allies (Lepus americanus and allies). In: Chapman JA, Feldhamer GA (eds) Wild mammals of North America. Baltimore, John Hopkins Univ Press, pp. 146-163

Bookhout TA (1965a) Feeding coactions between snowshoe hares and white-tailed deer in northern Michigan. Trans N Amer Wildl Conf and Nat Res 30:321-335

Bookhout TA (1965b) The snowshoe hare in upper Michigan: its biology and feeding coactions with white-tailed deer. Mich Dept Conserv Res and Develop Rep 38, p 191

Brand CJ, Keith LB, Fischer CA (1976) Lynx responses to changing snowshoe hare densities in central Alberta. J Wildl Manage $40: 416-428$
Brown JH (1981) Two decades of homage to Santa Rosalia: towards a general theory of diversity. Amer Zool 21:877-888

Colwell RK, Futuyma DJ (1971) On the measurement of niche breadth and overlap. Ecology 52:566-576

Conway CR, Glass NR, Wilcox JC (1970) Fitting non-linear models to biological data by Marquardt's algorithm. Ecology $51: 503-507$

Crombie AC (1947) Interspecific competition. I Anim Ecol $16: 44-73$

Dodds DG (1960) Food competition and range relationships of moose and snowshoe hare in Newfoundland. J Wildl Manage $24: 52-60$

Gause GF (1934) The struggle for existence. Hafner, New York

Gilpin ME, Ayala FJ (1973) Global models of growth and competition. Proc Nat Acad Sci 70:3590-3593

Gilpin ME, Ayala FJ (1976) Schoener's model and Drosophila competition. Theor Pop Biol 9:12-14

Gilpin ME, Justice KE (1972) Reinterpretation of the invalidation of the principle of competitive exclusion. Nature 236:273-301

Golley FB (1961) Energy values of ecological materials. Ecology 42:581-584

Horn HS (1966) Measurement of "overlap" in comparative ecological studies. Amer Nat 100:419-424

Hough AF (1949) Deer and rabbit browsing and available winter forage in Allegheny hardwood forests. J Wildl Manage 13:135-141

Hurlbert SH (1978) The measurement of niche overlap and some relatives. Ecology 59:67-77

Johnson WJ (1970) Food habits of the red fox in Isle Royale National Park, Lake Superior. Am Midl Nat 84:568-572

Keith LB (1967) Habitat vacancy during a snowshoe hare decline. J Wild Manage $31: 828-832$

Keith LB (1974) Some features of population dynamics in mammals. Proc Int Congr Game Biol No 11:17-58

Keith LB, Surrendi DC (1971) Effects of fire on a snowshoe hare population. J Wildl Manage 35:16-26

Keith LB, Windberg LA (1978) A demographic analysis of the snowshoe hare cycle. Wildl Monogr 58, p 78

Kleiber M (1961) The fire of life. Wiley, New York

Knorre EP (1959) Ecology of the moose. Trans of the PechoraIllych State Game Preserve, U.S.S.R. GA Novikov (ed). (Translated from the Russian by the Canadian Bureau of Indian Affairs) USSR Komi Book Publishers, Syktyvkat

Krefting LW (1953) Effect of simulated snowshoe hare and deer damage on planted conifers in the Lake States. J Wildl Manage 17:487-494

Krefting LW, Hansen HL, Meyer MP (1970) Vegetation type map of Isle Royale National Park. Bureau of Sports, Fish Wild!

Levins R (1968) Evolution in changing environments. Princeton Univ Press, Princeton New Jersey

Lotka AJ (1932) The growth of mixed populations: two species competing for a common food supply. J Wash Acad Sci 22:461-469

Marquardt DW (1963) An algorithm for least-squares estimation of non-linear parameters. J Soc Ind App Math 11:431-441

May RM (1975) Some notes on estimating the competition matrix, $\alpha$. Ecology $66: 737-741$

Mech LD (1966) The wolves of Isle Royale. US Nat Park Fauna 7

Mech LD (1974) A new profile of the wolf. Nat Hist 83:26-31

Menge BA, Sutherland JP (1976) Species diversity gradients: synthesis of the rates of predation, competition and temporal heterogeneity. Amer Nat 110:351-369

Moen A (1973) Wildlife ecology. WH Freeman Co, San Francisco

Mueller LD, Ayala FJ (1982) Dynamics of single-species population growth: experimental and statistical analysis. Theor Pop Biol 20:101-117

Neill WE (1974) The community matrix and interdependence of the competition coefficients. Amer Nat 108:399-408

Neyman J, Park T, Scott EL (1956) Struggle for existence. The Tribolium model: biological and statistical aspects. In: Proc 3rd Berkeley Symp on Mathematical Statistics and Probability, Vol IV. Univ Calif Press, Berkeley, p 41-79 
Peek JM (1982) Elk (Cervus elaphus). In: Chapman JA, Feldhamer GA (eds) Wild mammals of North America. Baltimore, John Hopkins Univ Press, pp 851-861

Pianka ER (1973) The structure of lizard communities. Ann Rev Ecol Syst 3:53-74

Pianka ER (1974) Niche overlap and diffuse competition. Proc Nat Acad Sci $71: 2141-2145$

Pianka ER (1975) Competition and niche theory. In: May R (ed) Theoretical ecology. Blackwell, London, pp 114-141

Raduchel WJ (1970) Regression analysis program for economists. Tech Paper 7, Harvard Inst Econ Res. Harvard Univ, Cambridge Massachusetts

Rusch DH, Meslow EC, Doerr PD, Keith LB (1972) Response of great horned owl populations to changing prey densities. $J$ Wild Manage 36:282-296

Schoener TW (1970) Non-synchronous spatial overlap of lizards in patchy environments. Ecology $51: 408-418$

Schoener TW (1971) Theory of feeding strategies. Ann Rev Ecol Syst 2:369-403

Schoener TW (1973) Population growth limited by intraspecific competition for energy of time: some simple representations. Theor Pop Biol 4:56-84

Schoener TW (1974a) Competition and the form of habitat shift. Theor Pop Biol 6:265-307

Schoener TW (1974b) Some methods for calculating competition coefficients from resource-utilization spectra. Amer Nat $108: 332-340$

Schoener TW (1975) Presence and absence of habitat shift in some widespread lizard species. Ecol Monogr 45:233-258

Schoener TW (1976) Alternatives to Lotka-Volterra competition models of intermediate complexity. Theor Pop Biol 10:309-333

Schoener TW (1978) Effects of density-restricted food encounter on some single-level competition models. Theor Pop Biol $13: 365-381$

Schoener TW (1983) Field experiments on interspecific competition literature. Amer Nat 122:240-285

Seegmiller RF, Ohmart RD (1981) Ecological relationships of feral burros and desert bighorn sheep. Wildl Monogr 78, p 58

Smith-Gill SJ, Gill DE (1978) Curvilinearities in the competition equations: an experiment with Ranid tadpoles. Amer Nat 112: $557-570$

Telfer ES (1972) Forage yield and browse utilization on logged areas in New Brunswick. Can J For Res 2:346-350

Tilman D (1980) Resources: a graphical mechanistic approach to competition and predation. Amer Nat 116:362-393

Tilman D (1982) Resource competition and community structure. Princeton Univ Press, Princeton

Tilman D, Kilham SS, Kilham P (1982) Phytoplankton community ecology: the role of limiting nutrients. Ann Rev Ecol Syst $13: 349-372$

Vandermeer JH (1969) The competitive structure of communities: an experimental approach with protozoa. Ecology 50:362-371

Volterra V (1926) Variazioni e fluttuazioni del numero d'individui in specie animali conviventi. Mem Acad Lincei 2:31-113

Vozeh GE, Cumming HG (1961) A moose population census and winter browse survey in Gogoma District, Ontario. Ontario Dept Lands and Forests, Toronto (Unpubl ms) p 31

Werner EE (1977) Species packing and niche complementarity in three sunfishes. Amer Nat 111:553-578

Wilbur HM (1972) Competition, predation and the structure of the Ambystoma-Rana sylvatica community. Ecology $53: 3-21$

Received August 1, 1983 